Check for updates

Cite this: RSC Adv., 2018, 8, 29008

Received 20th June 2018

Accepted 31st July 2018

DOI: $10.1039 / \mathrm{c} 8 \mathrm{ra05269g}$

rsc.li/rsc-advances

\section{A facile and highly sensitive resonance Rayleigh scattering-energy transfer method for urea using a fullerene probe}

\author{
Dongmei Yao, ${ }^{\text {ab }}$ Zining $\mathrm{He}^{\mathrm{a}}$ Guiqing Wen, ${ }^{\mathrm{a}}$ Aihui Liang ${ }^{\star a}$ and Zhiliang Jiang ${ }^{\star a}$ \\ Under ultrasound conditions, a deep yellow fullerene $\left(C_{60}\right)$ colloid was prepared, which exhibits two \\ resonance Rayleigh scattering peaks at $385 \mathrm{~nm}$ and $530 \mathrm{~nm}$. Urea was reacted with dimethylglyoxime \\ (DMG) to produce 4,5-dimethyl-2-imidazole ketone (DIK), in the presence of stabilizer \\ thiosemicarbazone (TSC). Resonance Rayleigh scattering energy transfer (RRS-ET) was shown to occur \\ between the donor fullerene and acceptor DIK due to an overlap of the DIK absorption and fullerene \\ RRS peaks. Upon an increase in the urea concentration, the RRS-ET was enhanced and the RRS intensity \\ decreased. The decreased RRS intensity was linear to the urea concentration in the range of 6.66- \\ $333.00 \mathrm{nmoL} \mathrm{L}{ }^{-1}$, with a detection limit of $2.0 \mathrm{nmoL} \mathrm{L}{ }^{-1}$. Accordingly, a new and simple RRS-ET method \\ was established for detecting trace levels of urea in foods, with satisfactory results.
}

\section{Introduction}

Urea is the end product of protein metabolism and is commonly used as a nitrogen fertilizer for plants. Due to it playing a significant role in the progress of social production, the determination of urea is very important in the food industry, agriculture and biochemistry. At present, the main analytical methods for the determination of urea are fluorescence spectrometry, ${ }^{1}$ electrochemistry, ${ }^{2-6}$ colorimetry, ${ }^{7,8}$ chemiluminescence, ${ }^{9}$ surface enhanced Raman scattering spectroscopy, ${ }^{\mathbf{1 0}}$ and resonance scattering spectroscopy. ${ }^{\mathbf{1 1}} \mathrm{A}$ copper nanocluster has previously been prepared that detects 0.25-5 mmol $\mathrm{L}^{-1}$ of urea using a fluorescence method, with

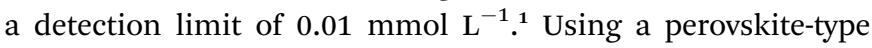
oxide and multiwalled carbon nanotube composite as a catalyst, 25-670 $\mu \mathrm{mol} \mathrm{L}{ }^{-1}$ of urea can be determined electrochemically. $^{2}$ A conducting polymer hydrogel (CPH) modified electrode was fabricated for the detection of 1.5-1000 $\mu \mathrm{mol} \mathrm{L}^{-1}$ of urea, with a detection limit of $60 \mathrm{nmol} \mathrm{L}{ }^{-1} \cdot{ }^{3}$ Jakhar et al. prepared urease nanoparticle aggregates as a biosensor for the potentiometric determination of $2-80 \mu \mathrm{mol} \mathrm{\textrm {L } ^ { - 1 }}$ of urea, with a detection limit of $1 \mu \mathrm{mol} \mathrm{L}{ }^{-1}{ }^{5}$ Based on a bioenzyme and the gold nanoparticle catalysis of 3,3,5,5-tetramethylbenzidine$\mathrm{H}_{2} \mathrm{O}_{2}, 5 \mathrm{~mol} \mathrm{~L}^{-1}$ of urea was detected spectrophotometrically. ${ }^{7}$ Nie et al. reported the chemiluminescent reaction of $\mathrm{N}$ -

${ }^{a}$ Key Laboratory of Ecology of Rare and Endangered Species and Environmental Protection (Guangxi Normal University), Ministry of Education, Guangxi Key Laboratory of Environmental Pollution Control Theory and Technology, Guilin 541004, China.E-mail: ahliang2008@163.com; zljiang@mailbox.gxnu.edu.cn

${ }^{b}$ College of Chemistry and Biology Engineering, Hechi University, Yizhou 546300, China bromosuccinimide and dichlorofluorescein for the detection of $2.0 \mathrm{ng} \mathrm{mL} \mathrm{m}^{-1}$ to $1.0 \mu \mathrm{g} \mathrm{mL}^{-1}$ of urea, with a detection limit of 0.7 $\mathrm{ng} \mathrm{m \textrm {m } ^ { - 1 } . 9}$ Using a composite of silver nanoparticles and porous gold nanoclusters as a SERS substrate, 1-20 $\mathrm{mmol} \mathrm{L}^{-1}$ urea was detected. ${ }^{10}$ To date, there have been no reports on the use of a RRS-ET method for the detection of urea.

Resonance Rayleigh scattering (RRS) is a simple, rapid and sensitive technique, and has been widely used in several fields, such as environmental analysis, biochemistry, and nanomaterial research. ${ }^{12-17}$ Yan et al. prepared a $\mathrm{Ag}_{2}$ Te nanocrystal (NC) RRS sensor for the detection of $0.026-9.87 \mu \mathrm{g} \mathrm{mL}{ }^{-1}$ of sulfide ions, with a detection limit of $7.8 \mathrm{ng} \mathrm{mL}{ }^{-1} \cdot{ }^{12}$ Ngernpimai et al. used positively charged gold nanorods and single stranded

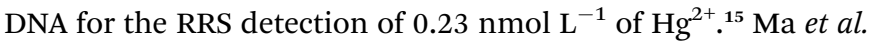
reported that chitosan interacted with erythrosine B (Ery B) to form an ion-associated complex of [Ery B-CTS], which increased the RRS intensity of the system, and 5.0-100.0 $\mathrm{ng} \mathrm{mL} \mathrm{mL}^{-1}$ of chitosan could be determined, with a detection limit of $0.47 \mathrm{ng}$ $\mathrm{mL}^{-1} \cdot{ }^{16}$ Ren et al. constructed a signal-on and label-free RRS aptasensor for the detection of $50.0 \mathrm{pmol} \mathrm{L}^{-1}-500.0 \mathrm{nmol} \mathrm{L}^{-1}$ of $\mathrm{Hg}^{2+} \cdot{ }^{17}$ Using graphene oxide (GO) as the RRS donor and the product of glutamic acid as an acceptor, a sensitive RRS-ET method was reported for the detection of $0.2-200 \mu \mathrm{mol} \mathrm{L}^{-1}$ of glutamic acid, with a detection limit of $0.08 \mu \mathrm{mol} \mathrm{L} \mathrm{L}^{-1} \cdot{ }^{\mathbf{1 4}}$ Fullerenes, allotropes of carbon, have been widely used in several fields because of its unique physical and chemical properties, and as a result they have found widespread use in a diverse range of fields, such as biomedicine, materials analysis, and bioengineering. ${ }^{18-23}$ A cerium dioxide $\left(\mathrm{CeO}_{2}\right)$-functionalized carboxyl fullerene $\left(\mathrm{c}-\mathrm{C}_{60}\right)$ electrochemical biosensor was developed to detect $1 \mathrm{fmol} \mathrm{L}^{-1}$ to $50 \mathrm{nmol} \mathrm{L}^{-1}$ of the CYP2C19*2 gene. $^{18}$ Water-soluble fullerene-graphene oxide 
$\left(\mathrm{C}_{60}-\mathrm{GO}\right)$ was utilized to detect $0.1-7.2 \mu \mathrm{mol} \mathrm{L}^{-1}$ of homovanilic acid ${ }^{20}$ So far, there have been no reports on the use of the RRSET method for the detection of urea using $\mathrm{C}_{60}$ as the RRS probe. Here, a new RRS-ET analysis platform was developed for the detection of urea in milk, with simple operation, good selectivity and high sensitivity.

\section{Experimental}

\subsection{Apparatus and reagents}

A F-7000 fluorescence spectrophotometer (HitachiCompany, Japan), a TU-1901 double-beam UV-visible spectrophotometer (Beijing Purkinje General Instrument Co., Ltd., China), a nanoparticle and zeta potential analyzer (Malvern company, UK), a HH-S2 thermostat water bath (Jintan earth automation instrument factory, China) and a SYZ-550 quartz sub-boiling distilled water apparatus (Jiangsu Jing glass instrument factory, China) were used.

$0.28 \mathrm{mmol} \mathrm{L}^{-1}$ fullerene solution (Xianfeng nano material technology Co., Ltd., China, with a no. of XFC00-2 and purity of $99.5 \mathrm{wt} \%$ ): $0.02 \mathrm{~g} \mathrm{C}_{60}$ was dissolved in $20 \mathrm{~mL}$ of methylbenzene. Then, $100 \mathrm{~mL}$ of water was added into the solution, and sonicated until the methylbenzene evaporated to leave a $0.28 \mathrm{mmol}$ $\mathrm{L}^{-1}$ fullerene solution. $166.5 \mu \mathrm{mol} \mathrm{L}{ }^{-1}$ urea standard solution: $1 \mathrm{mg}$ of urea was dissolved in $100 \mathrm{~mL}$ of water to obtain a 166.5 $\mu \mathrm{mol} \mathrm{L}{ }^{-1}$ urea solution, and serial dilution was used before use; $6 \mathrm{~mol} \mathrm{~L}^{-1} \mathrm{HCl}$; $0.258 \mathrm{~mol} \mathrm{~L}^{-1}$ dimethylglyoxime (DMG) solution: $0.18 \mathrm{~g}$ of DMG was dissolved in $6 \mathrm{~mL}$ of $6 \mathrm{~mol} \mathrm{~L}^{-1} \mathrm{HCl}$ to acquire a $0.258 \mathrm{~mol} \mathrm{~L}^{-1}$ DMG solution; $22 \mathrm{mmol} \mathrm{L}^{-1}$ thiosemicarbazone (TSC): $0.2004 \mathrm{~g}$ of TSC was dissolved in $100 \mathrm{~mL}$ of water to acquire a $22 \mathrm{mmol} \mathrm{L}^{-1}$ TSC solution. All reagents were of analytical grade and the water used in the experiments was double distilled.

\subsection{Procedure}

In a $5 \mathrm{~mL}$ marked test tube, a certain amount of urea, $150 \mu \mathrm{L}$ of $6 \mathrm{~mol} \mathrm{~L}^{-1} \mathrm{HCl}, 150 \mu \mathrm{L}$ of $22 \mathrm{mmol} \mathrm{L}^{-1} \mathrm{TSC}$, and $25 \mu \mathrm{L}$ of $0.258 \mathrm{~mol} \mathrm{~L}^{-1}$ DMG were added. After mixing well, the mixture was heated for $12 \mathrm{~min}$ in a $90{ }^{\circ} \mathrm{C}$ water bath and cooled using tap water. Then, $400 \mu \mathrm{L}$ of $0.28 \mathrm{mmol} \mathrm{L}^{-1}$ fullerene was added and diluted to $2 \mathrm{~mL}$ with water. The RRS spectrum was recorded, using a synchronous scanning technique $\left(\lambda_{\mathrm{ex}}-\lambda_{\mathrm{em}}=\Delta \lambda=\right.$ 0 ), a voltage of $350 \mathrm{~V}$, excitation and emission slits of $5.0 \mathrm{~nm}$, and an emission filter of $1 \% T$ attenuation. The RRS intensity at $530 \mathrm{~nm}(I)$ and the blank value without urea $\left(I_{0}\right)$ were measured, and the $\Delta I=I_{0}-I$ values were calculated.

\section{Results and discussion}

\subsection{Principle}

Fullerene have two strong RRS peaks at 385 and $530 \mathrm{~nm}$, and can be used as a RRS probe and donor in a RRS-ET analytical system. In the presence of the TSC stabilizer and $\mathrm{HCl}$ in a $90{ }^{\circ} \mathrm{C}$ water bath, urea reacted with DMG to form a red 4,5-dimethyl-2imidazolone (DIK) diazine derivative. Since the absorption spectrum of DIK overlaps with the RRS spectrum of $\mathrm{C}_{60}$, DIK can
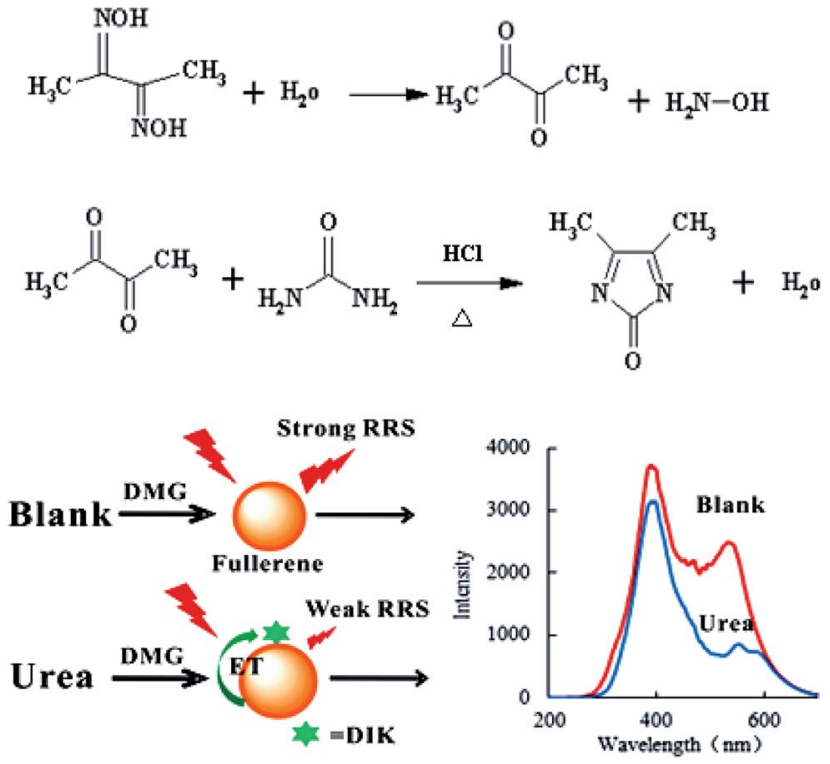

Fig. 1 Principles of the RRS-ET method for the detection of urea.

be used as an acceptor. When DIK adsorbs on the surface of $\mathrm{C}_{60}$, a surface plasmon RRS-ET effect occurs between the DIK and $\mathrm{C}_{60}$, which results in a decrease in the RRS intensity. Upon an increase in the urea concentration, there was an increase in the formation of DIK, and the RRS intensity at $530 \mathrm{~nm}$ decreased due to an enhancement in the RRS-ET (Fig. 1). Thus, a new $\mathrm{C}_{60}$ RRS-ET spectral method was established for the determination of trace amounts of urea.

\subsection{RRS spectra}

$\mathrm{C}_{60}$ is one of the most stable nanoparticle, and exhibits two RRS peaks at 385 and $530 \mathrm{~nm}$, of which the peak at $530 \mathrm{~nm}$ is the most sensitive. Thus, $\mathrm{C}_{60}$ was selected as a RRS probe. When heated at $90^{\circ} \mathrm{C}$ in a water bath, urea reacted with DMG to form DIK with weak RRS spectra. When $\mathrm{C}_{60}$ coexisted with DIK, the RRS intensity quenched gradually upon an increase in the amount of urea (Fig. 2).

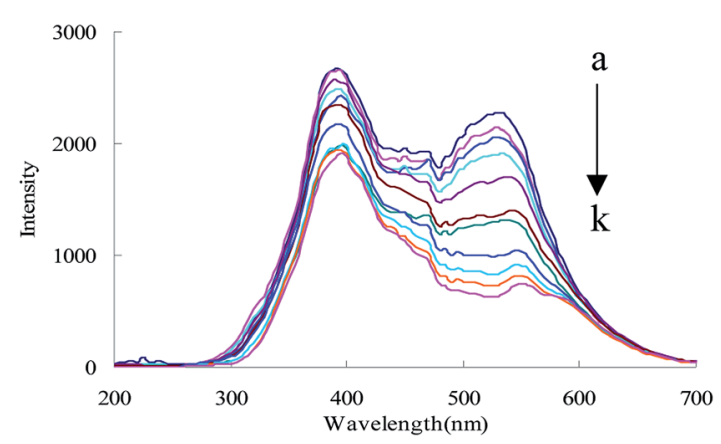

Fig. 2 RRS spectra of the urea-DMG- $\mathrm{C}_{60}$ system, (a): $0.45 \mathrm{~mol} \mathrm{~L}^{-1}$ of $\mathrm{HCl}+1.65 \mathrm{mmol} \mathrm{L}^{-1}$ of TSC $+3.2 \mathrm{mmol} \mathrm{L}^{-1}$ of DMG $+0.056 \mathrm{mmol} \mathrm{L}^{-1}$ of $C_{60}$; (b): $a+6.66 \mathrm{nmol} \mathrm{L}^{-1}$ of urea; (c): $a+16.65 \mathrm{nmol} \mathrm{L^{-1 }}$ of urea; (d): $a+49.95 \mathrm{nmol} \mathrm{L}{ }^{-1}$ of urea; (e): $a+83.25 \mathrm{nmol} \mathrm{L} \mathrm{L}^{-1}$ of urea; (f): $a+$ $133.20 \mathrm{nmol} \mathrm{L}{ }^{-1}$ of urea; (g): $a+166.50 \mathrm{nmol} \mathrm{L}{ }^{-1}$ of urea; (h): $a+$ $199.80 \mathrm{nmol} \mathrm{L}^{-1}$ of urea; (i): $a+233.10 \mathrm{nmol} \mathrm{L}^{-1}$ of urea; (j): $a+499.50$ nmol L $L^{-1}$ of urea; $(k): a+666.00 \mathrm{nmol} \mathrm{L^{-1 }}$ of urea. 


\subsection{Absorption spectra}

In $\mathrm{HCl}$ medium at $90^{\circ} \mathrm{C}$, urea reacted with DMG to form DIK, exhibiting an absorption peak at $530 \mathrm{~nm}$. The absorption peak value increased linearly with the urea concentration due to the formation of DIK (Fig. 3). However, its sensitivity was lower than the RRS-ET. In this study, urea reacted with DMG to form DIK with a strong absorption at around $530 \mathrm{~nm}$, as the acceptor, and $\mathrm{C}_{60}$ was observed to have a strong RRS signal at around $530 \mathrm{~nm}$, as the donor, and both the RRS and absorption spectra overlap (Fig. 4). When DIK adsorbed on the surface of $\mathrm{C}_{60}$, the RRS signal at $530 \mathrm{~nm}$ decreased due to the RRS energy transfer from the donor to the acceptor. This demonstrated that RRS-ET occurred.

\subsection{Laser scattering}

The size distribution of the laser scattering graph (Fig. 5) showed that before the addition of urea, the particle size of the system was $342 \mathrm{~nm}$. Upon the addition of urea, the particle size of the system increased from $342 \mathrm{~nm}$ to $411 \mathrm{~nm}$ due to the formation of DIK.

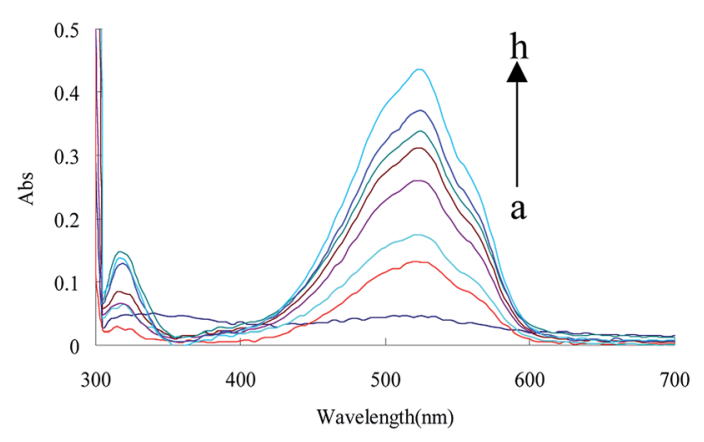

Fig. 3 Absorption spectra of the urea-DMG-C 60 system, (a) $0.45 \mathrm{~mol} \mathrm{~L}^{-1}$ of $\mathrm{HCl}+1.65 \times 10^{-3} \mathrm{~mol} \mathrm{~L}^{-1}$ of TSC $+3.2 \mathrm{mmol} \mathrm{L}^{-1}$ of $\mathrm{DMG}+0.056 \mathrm{mmol} \mathrm{L}^{-1}$ of $\mathrm{C}_{60}$; (b) $a+16.65 \mathrm{nmol} \mathrm{L}{ }^{-1}$ of urea; (c): $a+$ $66.60 \mathrm{nmol} \mathrm{L}^{-1}$ of urea; (d): $a+133.20 \mathrm{nmol} \mathrm{L}^{-1}$ of urea; (e): $a+233.10$ $\mathrm{nmol} \mathrm{L} \mathrm{L}^{-1}$ of urea; (f): $a+399.6 \mathrm{nmol} \mathrm{L}^{-1}$ of urea; $(\mathrm{g}): \mathrm{a}+499.50 \mathrm{nmol}$ $\mathrm{L}^{-1}$ of urea; (h): $a+666.0 \mathrm{nmol} \mathrm{L}^{-1}$ of urea.

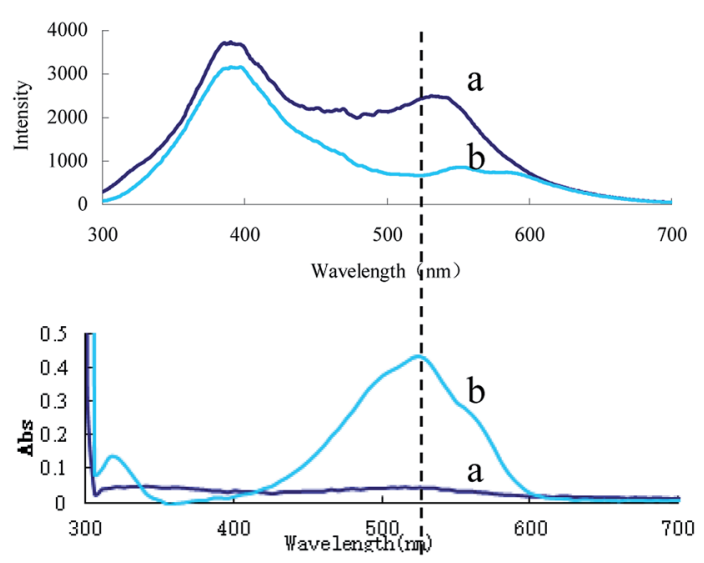

Fig. 4 Relationship between the RRS and absorption spectra of the urea-DMG- $\mathrm{C}_{60}$ system. (a): $0.45 \mathrm{~mol} \mathrm{~L}^{-1}$ of $\mathrm{HCl}+1.65 \times 10^{-3} \mathrm{~mol} \mathrm{~L}^{-1}$ of TSC $+3.2 \mathrm{mmol} \mathrm{L}^{-1}$ of DMG $+0.056 \mathrm{mmol} \mathrm{L}^{-1}$ of $\mathrm{C}_{60} ;(\mathrm{b}): \mathrm{a}+666.0$ $\mathrm{nmol} \mathrm{L}^{-1}$ of urea.

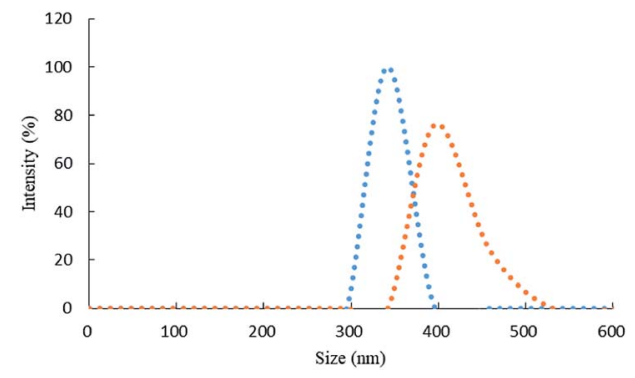

Fig. 5 Laser scattering graph of the urea-DMG- $\mathrm{C}_{60}$ system, (a): $0.45 \mathrm{~mol} \mathrm{~L}^{-1}$ of $\mathrm{HCl}+1.65 \times 10^{-3} \mathrm{~mol} \mathrm{~L}^{-1}$ of TSC $+3.2 \mathrm{mmol} \mathrm{L}^{-1}$ of $\mathrm{DMG}+0.056 \mathrm{mmol} \mathrm{L}^{-1}$ of $\mathrm{C}_{60} ;(\mathrm{b}): \mathrm{a}+166.5 \mathrm{nmol} \mathrm{L}-1$ of urea.

\subsection{Optimization of the analytical conditions}

The effect of reagent concentration on the determination was studied and the effect of $\mathrm{HCl}$ concentration on the $\Delta I$ value was tested. When the $\mathrm{HCl}$ concentration was $0.45 \mathrm{~mol} \mathrm{~L}^{-1}$ (Fig. 6), the TSC concentration was $1.65 \mathrm{mmol} \mathrm{L}^{-1}$ (Fig. 7), the DMG concentration was $3.2 \mathrm{mmol} \mathrm{L}^{-1}$ (Fig. 8), the $\mathrm{C}_{60}$ concentration was $0.056 \mathrm{mmol} \mathrm{L}^{-1}$ (Fig. 9), the temperature was $90^{\circ} \mathrm{C}$ (Fig. 10), and the bath time was $12 \mathrm{~min}$ (Fig. 11), respectively determined,

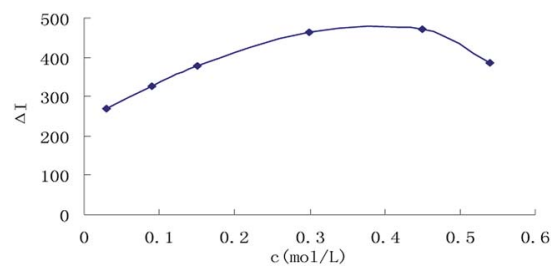

Fig. 6 Effect of $\mathrm{HCl}$ concentration, $133.20 \mathrm{nmol} \mathrm{L}{ }^{-1}$ of urea $+\mathrm{HCl}+$ $1.65 \mathrm{mmol} \mathrm{L}^{-1}$ of TSC $+3.2 \mathrm{mmol} \mathrm{L^{-1 }}$ of DMG $+0.056 \mathrm{mmol} \mathrm{L}^{-1}$ of $\mathrm{C}_{60}$.

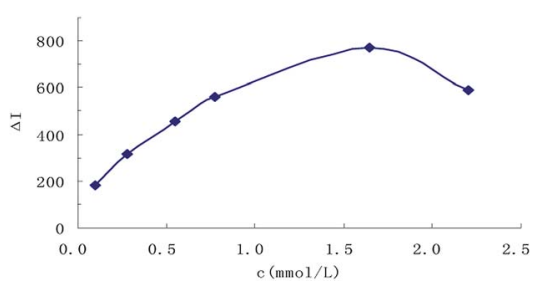

Fig. 7 Effect of TSC concentration, $133.20 \mathrm{nmol} \mathrm{L^{-1 }}$ of urea + $0.45 \mathrm{~mol} \mathrm{~L}^{-1} \mathrm{HCl}+\mathrm{TSC}+3.2 \mathrm{mmol} \mathrm{L}^{-1} \mathrm{DMG}+0.056 \mathrm{mmol} \mathrm{L}^{-1}$ of $\mathrm{C}_{60}$.

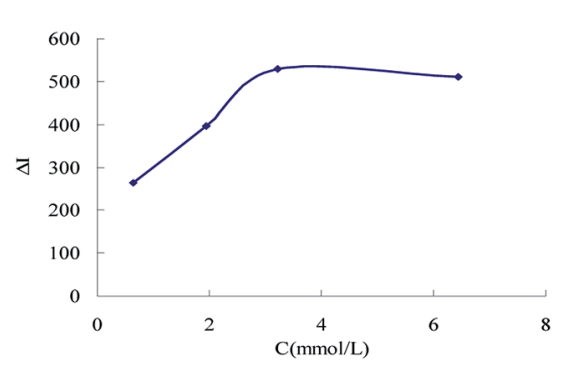

Fig. 8 Effect of DMG concentration, $133.20 \mathrm{nmol} \mathrm{L}^{-1}$ of urea + $0.45 \mathrm{~mol} \mathrm{~L}^{-1}$ of $\mathrm{HCl}+1.65 \mathrm{mmol} \mathrm{L}^{-1}$ of TSC + DMG $+0.056 \mathrm{mmol} \mathrm{L}^{-1}$ of $\mathrm{C}_{60}$. 


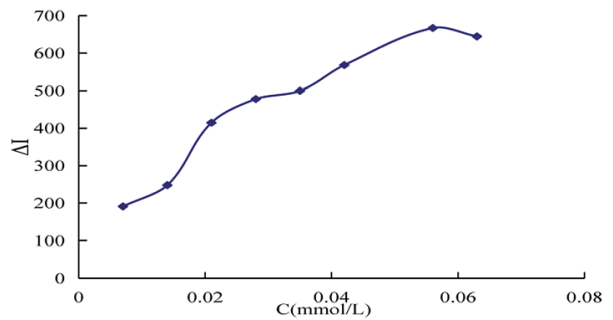

Fig. 9 Effect of $\mathrm{C}_{60}$ concentration, $133.20 \mathrm{nmol} \mathrm{L^{-1 }}$ of urea + $0.45 \mathrm{~mol} \mathrm{~L}^{-1}$ of $\mathrm{HCl}+1.65 \mathrm{mmol} \mathrm{L}^{-1}$ of TSC $+3.2 \mathrm{mmol} \mathrm{L}^{-1}$ of DMG + $\mathrm{C}_{60}$.

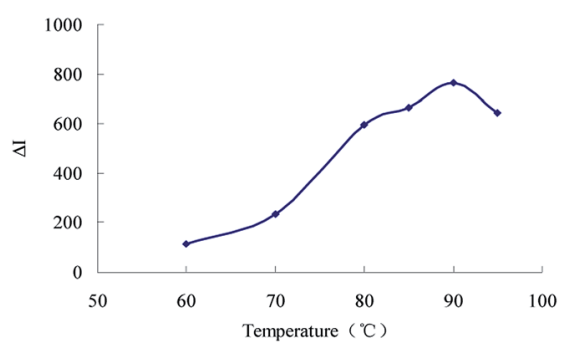

Fig. 10 Effect of bath temperature $133.20 \mathrm{nmol} \mathrm{L}^{-1}$ of urea + $0.45 \mathrm{~mol} \mathrm{~L}^{-1}$ of $\mathrm{HCl}+1.65 \mathrm{mmol} \mathrm{L}^{-1}$ of TSC $+3.2 \mathrm{mmol} \mathrm{L}^{-1}$ of DMG + $0.056 \mathrm{mmol} \mathrm{L}^{-1}$ of $\mathrm{C}_{60}$.

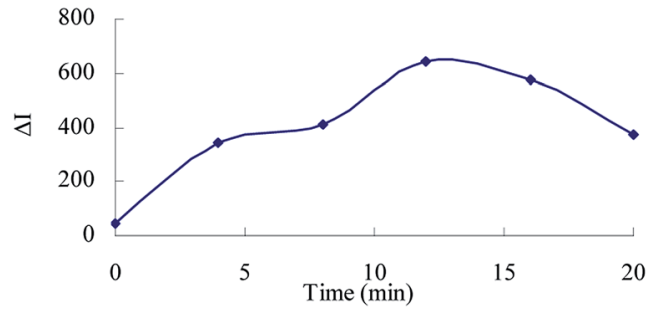

Fig. 11 Effect of bath time $133.20 \mathrm{nmol} \mathrm{L}{ }^{-1}$ of urea $+0.45 \mathrm{~mol} \mathrm{~L}^{-1}$ of $\mathrm{HCl}+1.65 \mathrm{mmol} \mathrm{L}^{-1}$ of TSC $+3.2 \mathrm{mmol} \mathrm{L}^{-1}$ of DMG $+0.056 \mathrm{mmol} \mathrm{L}^{-1}$ of $\mathrm{C}_{60}$.

the $\Delta I$ value was at its maximum and these parameters were therefore considered to be the optimum conditions.

\subsection{Influence of coexisting substances}

According to the procedure, the interference of coexisting substances on the determination of $133.20 \mathrm{nmol} \mathrm{L}^{-1}$ of urea was tested, with a relative error of $\pm 10 \%$, as shown in Table 1 . The results indicate that $6.66 \mu \mathrm{mol} \mathrm{L}{ }^{-1}$ of $\mathrm{Zn}^{2+}, \mathrm{Ba}^{2+}, \mathrm{Cr}^{6+}$, ethanediol, creatine, $\mathrm{Cu}^{2+}, \mathrm{Fe}^{3+}, \mathrm{Bi}^{3+}, \mathrm{SO}_{4}{ }^{2-}$, glycine, hexamethylenetetramine, edetate disodium and $1.332 \mu \mathrm{mol} \mathrm{L}{ }^{-1}$ of $\mathrm{Mn}^{2+}, \mathrm{Ca}^{2+}$, $\mathrm{Al}^{3+}, \mathrm{K}^{+}, \mathrm{Pb}^{2+}, \mathrm{NH}_{4} \mathrm{Cl}, \mathrm{Co}^{2+}, \mathrm{NO}^{2-}$, and $\mathrm{Mg}^{2+}$ have little effect on the determination. This shows that the SERS method described in this work has good selectivity.

\subsection{Working curve}

Using the selected conditions, the RRS intensity for different urea concentrations was recorded. The working curve was drawn according the relationship between the urea and the
Table 1 Influence of coexistent substances

\begin{tabular}{|c|c|c|}
\hline Coexisting substance & Tolerance (times) & Relative error (\%) \\
\hline $\mathrm{Zn}^{2+}$ & 50 & -5.6 \\
\hline $\mathrm{Mn}^{2+}$ & 10 & -7.5 \\
\hline $\mathrm{Ba}^{2+}$ & 50 & 2.8 \\
\hline $\mathrm{Ca}^{2+}$ & 10 & 4.8 \\
\hline $\mathrm{Al}^{3+}$ & 10 & 3.5 \\
\hline $\mathrm{Pb}^{2+}$ & 10 & 4.8 \\
\hline $\mathrm{Cr}^{6+}$ & 50 & -7.3 \\
\hline Ethanediol & 50 & 6.0 \\
\hline $\mathrm{NH}_{4} \mathrm{Cl}$ & 10 & -0.4 \\
\hline $\mathrm{NO}^{2-}$ & 10 & -5.3 \\
\hline $\mathrm{Mg}^{2+}$ & 10 & 2.2 \\
\hline $\mathrm{Cu}^{2+}$ & 50 & 0.4 \\
\hline $\mathrm{K}^{+}$ & 10 & 6.3 \\
\hline $\mathrm{Fe}^{3+}$ & 50 & -7.0 \\
\hline $\mathrm{Bi}^{3+}$ & 50 & 8.9 \\
\hline $\mathrm{SO}_{4}^{2-}$ & 50 & -7.0 \\
\hline Ethyl alcohol & 100 & 0.6 \\
\hline Glycine & 50 & 0.7 \\
\hline $\mathrm{Co}^{2+}$ & 10 & 3.4 \\
\hline Hexamethylenetetramine & 50 & -7.0 \\
\hline Hydrazine hydrochloride & 100 & 3.0 \\
\hline Edetate disodium & 50 & -4.2 \\
\hline Creatine & 50 & 1.3 \\
\hline
\end{tabular}

corresponding $\Delta I$ values (Fig. 12). The linear range was found to be 6.66-233.10 nmoL $\mathrm{L}^{-1}$, with a regression equation of $\Delta I=$ $5.89 c+70.63$, a coefficient of 0.992 , and the detection limit was $2.0 \mathrm{nmoL} \mathrm{L}{ }^{-1}$. From a comparison of reported assays (Table 2), this method was found to be simple and sensitive.

\subsection{Analysis of samples}

Three samples of pure milk, A, B and C, were purchased from a large supermarket. In a $2 \mathrm{~mL}$ marked test tube, $1.4 \mathrm{~mL}$ of sample and $600 \mu \mathrm{L}$ of acetic acid $(\mathrm{v} / \mathrm{v}=3 \%)$ were added and the solution was mixed well. The resulting mixture was centrifuged for $3 \mathrm{~min}$ at $3500 \mathrm{rpm}$. Then, $1 \mathrm{~mL}$ of supernatant and $150 \mu \mathrm{L}$ of $6 \mathrm{~mol} \mathrm{~L}^{-1} \mathrm{HCl}$ were added into a $2 \mathrm{~mL}$ marked test tube, and diluted to $2 \mathrm{~mL}$. Then the mixed solution was centrifuged for $3 \mathrm{~min}$ at $7000 \mathrm{rpm}$. Finally, $1 \mathrm{~mL}$ of supernatant was diluted to $5 \mathrm{~mL}$ to obtain the sample solution. A certain volume of the sample solution was used for detection according to the procedure. Recovery was carried out at the same time, and was found to be in the range of $93.3-101.7 \%$, with a relative standard deviation (RSD) in the range of $2.37-5.12 \%$ (Table 3 ).

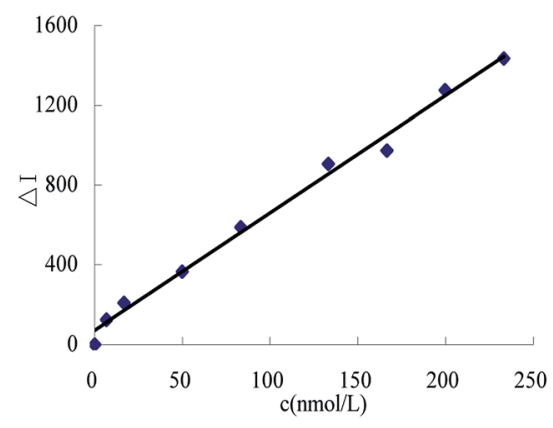

Fig. 12 The working curve. 
Table 2 Comparison of some of the reported analytical methods used for detecting urea

\begin{tabular}{llll}
\hline Method & Linear range & Detection limit & Comments \\
\hline Fluorescence & $0.25-5 \mathrm{mmol} \mathrm{L}^{-1}$ & $0.01 \mathrm{mmol} \mathrm{L}^{-1}$ & Low sensitivity \\
Electrochemistry & $1.5-1000 \mu \mathrm{mol} \mathrm{L}^{-1}$ & $60 \mathrm{nmol} \mathrm{L}^{-1}$ & Wide linear range and sensitivity \\
Colorimetry & $0.02-0.4 \mathrm{mmol} \mathrm{L}^{-1}$ & $5 \mu \mathrm{mol} \mathrm{L}^{-1}$ & Simple, but low sensitivity \\
Chemilumine-scence & $0.002-1.0 \mu \mathrm{g} \mathrm{mL}^{-1}$ & $0.7 \mathrm{ng} \mathrm{mL}^{-1}$ & Wide linear range, sensitive \\
SERS & $1-20 \mathrm{mmol} \mathrm{L}^{-1}$ & - & Low sensitivity \\
RRS & $7.58 \times 10^{-3}-0.91 \mathrm{mg} \mathrm{mL}^{-1}$ & $3.51 \mu \mathrm{m} \mathrm{mL}^{-1}$ & High sensitivity, complex \\
RRS & $6.66-233.10 \mathrm{nmoL} \mathrm{L}^{-1}$ & $2.0 \mathrm{nmoL} \mathrm{L}^{-1}$ & Simple, sensitive
\end{tabular}

Table 3 Results for the detection of urea in samples

\begin{tabular}{|c|c|c|c|c|c|c|}
\hline A & 88.65 & 33.30 & 120.79 & 96.5 & 2.37 & 36.19 \\
\hline $\mathrm{C}$ & 62.37 & 33.30 & 93.44 & 93.3 & 5.12 & 25.46 \\
\hline
\end{tabular}

\section{Conclusions}

In summary, based on a RRS-ET analytical platform and coupling of a RRS $\mathrm{C}_{60}$ donor probe and DIK receptor, the decreased RRS intensity $(\Delta I)$ was found to be linear to urea concentration in the range of $6.66-233.10 \mathrm{nmoL} \mathrm{L} \mathrm{L}^{-1}$, with a detection limit of $2.0 \mathrm{nmoL} \mathrm{L}^{-1}$. Thus, the RRS method was developed for the determination of trace amounts of urea, with simplicity, good selectivity and high sensitivity. The method was applied to detect urea in food, and the results were found to be satisfactory.

\section{Conflicts of interest}

The authors declare no competing financial interest.

\section{Acknowledgements}

This work was supported by the National Natural Science Foundation of China (No. 21667006, 21767004, 21465006, 21477025) and the Natural Science Foundation of Guangxi (No. 2018GXNSFAA138019).

\section{References}

1 H. Deng, K. Li, Q. Zhuang, H. Peng, Q. Zhuang, A. Liu, X. Xia and W. Chen, Nanoscale, 2018, 10, 6467-6473.

2 T. Q. N. Tran, S. W. Yoon, B. J. Park and H. H. Yoon, J. Electroanal. Chem., 2018, 818, 76-83.

3 J. Das and P. Sarkar, RSC Adv., 2016, 6, 92520-92533.

4 R. Sha, K. Komori and S. Badhulika, Electrochim. Acta, 2017, 233, 44-51.

5 S. Jakhar and C. S. Pundir, Biosens. Bioelectron., 2018, 100, 242-250.

6 D. Dutta, S. Chandra, A. K. Swain and D. Bahadur, Anal. Chem., 2014, 86, 5914-5921.
7 H. Deng, G. Hong, F. Lin, A. Liu, X. Xia and W. Chen, Anal. Chim. Acta, 2016, 915, 74-80.

8 A. W. Zaibudeen and J. Philip, Sens. Actuators, B, 2018, 255, 720-728.

9 F. Nie, N. Wang, P. Xu and J. Zheng, J. Food Drug Anal., 2017, 25, 472-477.

10 Y. Li, Q. Li, C. Sun, S. Jin, Y. Park, T. Zhou, X. Wang, B. Zhao, W. Ruan and Y. M. Jung, Appl. Surf. Sci., 2018, 427, 328-333.

11 A. Liang, H. Qin, L. Zhou, Y. Zhang, H. Ouyang, P. Wang and Z. Jiang, Bioprocess Biosyst. Eng., 2011, 34, 639-645.

12 S. Yan, R. Song and Y. Tang, Anal. Methods, 2016, 8, 37683773.

13 H. Ouyang, A. Liang and Z. Jiang, Spectrochim. Acta, Part A, 2018, 190, 268-273.

14 Y. Luo, C. Li, A. Qin, A. Liang and Z. Jiang, J. Lumin., 2017, 185, 174-179.

15 S. Ngernpimai, P. Matulakun, S. Teerasong, T. Puangmali, A. Kopwitthaya, S. Kanokmedhakul, D. Sangiamdee and A. Chompoosor, Sens. Actuators, B, 2018, 255, 836-842.

16 C. Ma, W. Zhang, Z. Su and Y. Bai, Food Chem., 2018, 239, 126-131.

17 W. Ren, Y. Zhang, H. G. Chen, Z. F. Gao, N. B. Li and H. Q. Luo, Anal. Chem., 2016, 88, 1385-1390.

18 C. Zhang, J. He, Y. Zhang, J. Chen, Y. Zhao, Y. Niu and C. Yu, Biosens. Bioelectron., 2018, 102, 94-100.

19 D. Saha and S. Das, Mater. Today, 2018, 5, 9817-9825.

20 J. A. Rather, E. A. Khudaish, A. Munam, A. Qurashi and P. Kannan, Sens. Actuators, B, 2016, 237, 672-684.

21 Z. Maniei, E. Shakerzadeh and Z. Mahdavifar, Chem. Phys. Lett., 2018, 691, 360-365.

22 M. Sun, A. Kiourti, H. Wang, S. Zhao, G. Zhao, X. Lu, J. L. Volakis and X. He, Mol. Pharm., 2016, 13, 2184-2192.

23 S. Bashiri, E. Vessally, A. Bekhradnia, A. Hosseinian and L. Edjlali, Vacuum, 2017, 136, 156-162. 